University of Nebraska - Lincoln

DigitalCommons@University of Nebraska - Lincoln

Subspecific Relationships and Genetic Structure in the Spotted Owl

Susan M. Haig

U.S. Geological Survey, Susan_Haig@usgs.gov

Thomas D. Mullins

U.S. Geological Survey, tom_mullins@usgs.gov

Eric D. Forsman

U.S. Gorest Service

Follow this and additional works at: https://digitalcommons.unl.edu/usgsstaffpub

Part of the Geology Commons, Oceanography and Atmospheric Sciences and Meteorology Commons, Other Earth Sciences Commons, and the Other Environmental Sciences Commons

Haig, Susan M.; Mullins, Thomas D.; and Forsman, Eric D., "Subspecific Relationships and Genetic Structure in the Spotted Owl" (2004). USGS Staff -- Published Research. 672.

https://digitalcommons.unl.edu/usgsstaffpub/672

This Article is brought to you for free and open access by the US Geological Survey at DigitalCommons@University of Nebraska - Lincoln. It has been accepted for inclusion in USGS Staff -- Published Research by an authorized administrator of DigitalCommons@University of Nebraska - Lincoln. 


\title{
Subspecific relationships and genetic structure in the spotted owl
}

\author{
Susan M. Haig ${ }^{1 *}$, Thomas D. Mullins ${ }^{1} \&$ Eric D. Forsman ${ }^{2}$ \\ ${ }^{1}$ USGS Forest and Rangeland Ecosystem Science Center, 3200 SW Jefferson Way, Corvallis, OR 97331, \\ USA; ${ }^{2}$ U.S. Forest Service Pacific Northwest Research Station, 3200 SW Jefferson Way, Corvallis, OR \\ 97331, USA; (*Author for correspondence: Phone: 541-750-7482; fax: 541-758-8806; e-mail: susan_haig@ \\ usgs.gov)
}

Received 22 July 2003; accepted 24 April 2004

Key words: control region, cytochrome $b$, intraspecific hybridization, mitochondrial DNA, phylogeography, population structure, spotted owls, Strix occidentalis, subspecies

\begin{abstract}
Hierarchical genetic structure was examined in the three geographically-defined subspecies of spotted owl (Strix occidentalis) to define relationships among subspecies and quantify variation within and among regional and local populations. Sequences $(522 \mathrm{bp}$ ) from domains I and II of the mitochondrial control region were analyzed for 213 individuals from 30 local breeding areas. Results confirmed significant differences between northern spotted owls and the other traditional geographically defined subspecies but did not provide support for subspecific level differences between California and Mexican spotted owls. Divergence times among subspecies estimated with a $936 \mathrm{bp}$ portion of the cytochrome $b$ gene dated Northern and California/Mexican spotted owl divergence time to 115,000-125,000 years ago, whereas California/Mexican spotted owl divergence was estimated at 15,000 years ago. Nested clade analyses indicated an association between California spotted owl and Mexican spotted owl haplotypes, implying historical contact between the two groups. Results also identified a number of individuals geographically classified as northern spotted owls (S. o. caurina) that contained haplotypes identified as California spotted owls (S. o. occidentalis). Among all northern spotted owls sampled $(\mathrm{n}=131), 12.9 \%$ contained California spotted owl haplotypes. In the Klamath region, which is the contact zone between the two subspecies, $20.3 \%(\mathrm{n}=59)$ of owls were classified as California spotted owls. The Klamath region is a zone of hybridization and speciation for many other taxa as well. Analyses of population structure indicated gene flow among regions within geographically defined subspecies although there was significant differentiation among northern and southern regions of Mexican spotted owls. Among all areas examined, genetic diversity was not significantly reduced except in California spotted owls where the southern region consists of one haplotype. Our results indicate a stable contact zone between northern and California spotted owls, maintaining distinct subspecific haplotypes within their traditional ranges. This supports recovery efforts based on the traditional subspecies designation for the northern spotted owl. Further, although little variation was found between California and Mexican spotted owls, we suggest they should be managed separately because of current isolation between groups.
\end{abstract}

\section{Introduction}

The vagility of birds has frequently given rise to hybridization among closely-related species. Use of mitochondrial markers has been helpful in resolving these relationships (e.g., Avise et al.
1990; Tegelstrom and Gelter 1990; Seutin et al. 1993; Zink 1994; Lovette et al. 1999; Sattler and Braun 2000; Rohwer et al. 2001). The implications of this hybridization to speciation and conservation status can be profound (Rhymer and Simberloff 1996; Wolf et al. 2001; Allendorf et al. 
2001; Haig et al. 2004; Haig and Allendorf 2004). While commonly occurring, less attention has been directed at intraspecific hybridization, introgression, and genetic mixing in birds (although see Fleischer et al. 1991; Zink et al. 1991, 2001; Goodstrey et al. 1998; Bensch et al. 1999; Rhymer et al. 2001; Glenn et al. 2002). Furthermore, a recent decision by the U.S. Fish and Wildlife Service to list distinct population segments under the U.S. Endangered Species Act has stimulated greater interest in these topics. To date, most of these cases have involved non-avian taxa (e.g., Allendorf and Leary 1988; Bernatchez 1995; Firestone et al. 1999; Parker et al. 1999; Roman et al. 1999; although see Avise and Nelson 1989; Young and Allard 1997; Nelson et al. 2000; Zink et al. 2000). In this study, we examine population structure as well as relationships within and among geographically-defined subspecies for a threatened avian species with little morphological variation yet historical divergence among subspecies. Subspecific definition and identification of contact among subspecies has immediate consequences for their listing and/or delisting under the U.S. Endangered Species Act.

The spotted owl (Strix occidentalis) is one of the USA's most controversial threatened species. Issues surrounding the species have arisen from their association with declining, fragmented, latesuccessional forests in the Pacific Northwest and Southwestern U.S. (Thomas et al. 1990; U.S. Forest Service and U.S. Bureau of Land Management 1994; U.S. Fish and Wildlife Service 1995). Spotted owls are long-lived, primarily nonmigratory, have high site fidelity, low reproductive rates, and large home ranges (summarized in Forsman et al. 1984, 2002; Franklin et al. 2004; Gutiérrez et al. 1995, Miller et al. 1997).

Spotted owls have a locally fragmented, but almost continuous distribution from British Columbia to central Mexico (Figure 1, Gutiérrez et al. 1995). Currently, there are three recognized subspecies (American Ornithologists' Union 1957, Figure 1). Northern spotted owls (NSO, S. o. caurina) are resident from southern British Columbia to central California. California spotted owls (CSO, S. o. occidentalis) occur in the Sierra Nevada Mountains in eastern California and coast ranges in southern California. Mexican spotted owls (MSO, S. o. lucida) are distributed in a network of island populations in the canyonlands of the southwest U.S. through central Mexico (Gutiérrez et al. 1995). Initial subspecies designations were based on plumage color and body size (Oberholser 1915), although significant differences have not been described (Gutiérrez et al. 1995).

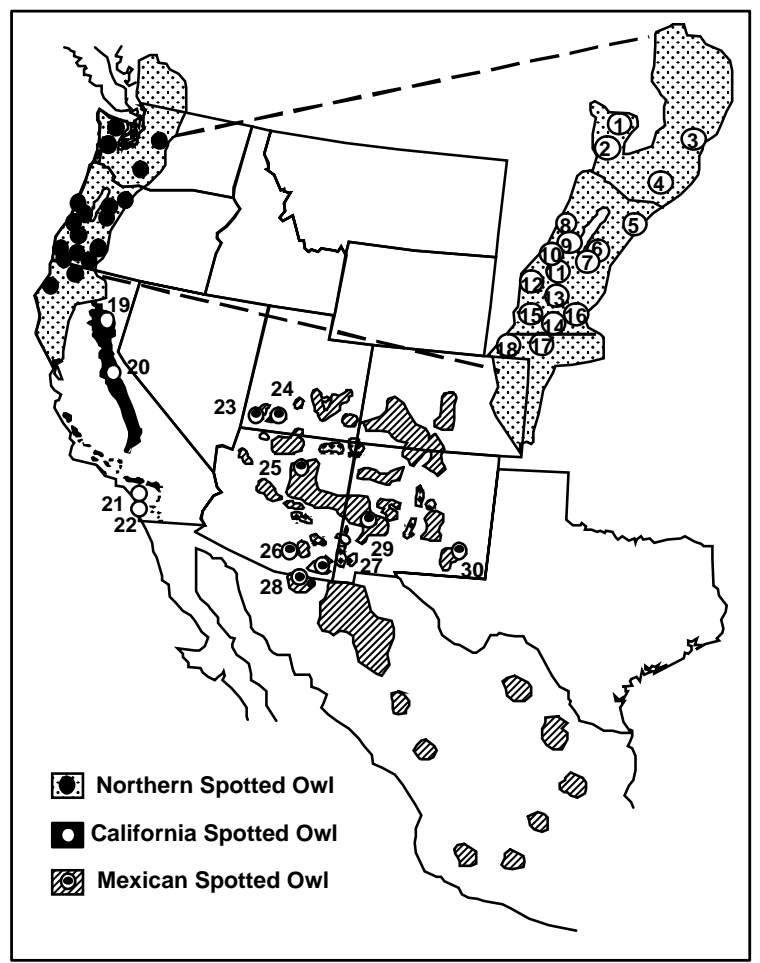

Figure 1. Range of the spotted owl (modified from Gutiérrez et al. 1995) and locations of sampling sites in Washington (WA), Oregon (OR), California (CA), Utah (UT), Arizona (AZ), and New Mexico (NM). 1. QUIL - Olympic National Forest, Quilcene, WA; 2. QUIN - Olympic National Forest, Quinault, WA; 3. WENA - Wenatchee National Forest, WA; 4. YAKI - Yakima Indian Reservation, WA; 5. WSPR - Warm Springs Indian Reservation, OR; 6. EUCA - Eugene BLM district (Cascades), OR; 7. WLNF - Willamette National Forest, OR; 8. WALD - Siuslaw National Forest, Waldport, OR; 9. ALSE - Siuslaw National Forest, Alsea, OR; 10. MAPL - Siuslaw National Forest, Mapleton, OR; 11. EUCO - Eugene BLM District (Coast Range); 12. COOS - Coos Bay, OR; 13. ROSE - Roseburg BLM District, OR; 14. JACK - Jackson Co., OR; 15. JOSE - Josephine Co., OR; 16. KLCO - Klamath Co., OR; 17. KLNF - Klamath National Forest, OR/CA; 18. HUMB - Humboldt Co, CA; 19. LASS - Lassen National Forest, CA; 20. FRES - Fresno, CA; 21. SBER - San Bernadino Range, CA; 22. SJAC - Mount San Jacinto, CA; 23. ZION - Zion National Park, UT; 24. CAPR - Capitol Reef National Park, UT; 25. COPL - Coconino Plateau, AZ; 26. PIMA - Pima Co., AZ; 27. COCH - Cochise Co., AZ; 28. SCRZ - Santa Cruz Co., AZ; 29. TULA - Tularosa Mts, NM; 30. SACR - Sacramento Mts, NM. 
Recent mitochondrial analyses support the historic presence of three evolutionary lineages concordant with current geographically-defined subspecies designations in spotted owls (Barrowclough et al. 1999). However, more detailed sampling including the contact zone between northern and California spotted owls using random amplified polymorphic DNA did not support these divisions (Haig et al. 2001). In this study, we use more extensive sampling to further examine population structure and relationships among traditionally (geographically) defined spotted owl subspecies to better clarify these issues. Currently, northern and Mexican spotted owls are listed as threatened (55 Federal Register 11413, 55 Federal Register 26114) and the northern spotted owl is currently undergoing a federal status review. The California spotted owl was recently rejected for listing under the U.S. Endangered Species Act, although additional petitions have been filed. Clarification of taxonomic status and population structure is essential in all of these deliberations.

\section{Methods}

\section{Sample collection}

Blood samples were collected from individuals captured at 22 local breeding areas among the three geographically-defined subspecies of spotted owls during routine field work (Figure 1). No known close relatives (e.g., parent/offspring, siblings, etc.) were included in the sampling. Following guidelines approved by the American Ornithologists' Union (Oring et al. 1988), blood samples $(0.5 \mathrm{ml})$ were collected from the brachial vein with a 26 gauge needle. Blood was stored in cryogenic tubes containing a buffer solution (100 mM Tris- $\mathrm{HCl}, \mathrm{pH} 8.0,100 \mathrm{mM}$ EDTA pH $8.0,10 \mathrm{mM} \mathrm{NaCl}, 0.5 \%$ SDS) and frozen at $-80{ }^{\circ} \mathrm{C}$ until analysis.

In addition to samples collected by the authors, eight additional breeding areas were included in the study via use of sequence data from Barrowclough et al. (1999). These included owls from the Willamette National Forest, OR; San Bernadino Mountains, CA; Mount San Jacinto, CA; Zion National Park, UT; Capitol Reef National Park, UT; Coconino Plateau, AZ; Tularosa
Mountains, NM; and Sacramento Mountains, AZ (Figure 1).

Aside from subspecies designations outlined by the American Ornithologists' Union (1957), there are no previously published a priori groupings (i.e., in recovery plans, metapopulation discussions, etc.) of spotted owls. Thus, we grouped samples by geography and potential geographic barriers to dispersal at three levels: local breeding areas, regions, and subspecies. Breeding areas were classified by the study area in which samples were collected. Regional groups were defined by significant geographic features (e.g., Olympic Range, Cascade Range, Sierras) or by extreme geographic distances between areas. The Klamath region was defined by the geographic provinces known as Oregon Klamath and California Klamath Provinces. Subspecies were geographically defined by the American Ornithologists Union (1957).

\section{Molecular methods}

DNA was obtained by a standard phenol/chloroform extraction as previously reported (Haig et al. 1994). Briefly, $10 \mu \mathrm{l}$ of blood was digested in

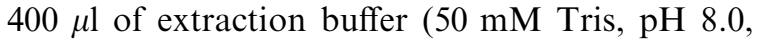
$10 \mathrm{mM}$ EDTA, pH 8.0, $200 \mathrm{mM} \mathrm{NaCl}, 2 \%$ SDS) with Proteinase K $(20 \mathrm{mg} / \mathrm{ml})$ added to a final concentration of $600 \mu \mathrm{g} / \mathrm{ml}$. Samples were then vortexed and incubated overnight $(\sim 18 \mathrm{~h})$ at $50{ }^{\circ} \mathrm{C}$. If blood clots were not fully dispersed, a second aliquot of Proteinase $\mathrm{K}$ was added and the samples were incubated an additional $2 \mathrm{~h}$. Samples were extracted with equal volumes of phenol (saturated with $10 \mathrm{mM}$ Tris, $\mathrm{pH}$ 8.0) and then chloroform/isoamyl alcohol (25:1). DNA was precipitated by adding a $1 / 10$ volume of $3 \mathrm{M}$ sodium acetate and two volumes of cold $95 \%$ ethanol and pelleted at approximately $15,000 \mathrm{~g}$ for $20 \mathrm{~min}$ in a microcentrifuge. Pellets were washed once with $70 \%$ ethanol, dried under vacuum and resuspended in $30 \mu \mathrm{l}$ TE $(10 \mathrm{mM}$ Tris, $\mathrm{pH} 8.0$, $0.1 \mathrm{mM}$ EDTA, $\mathrm{pH}$ 8.0). DNA concentration of samples was quantified with a Hoefer TKO 100 fluorometer and working solutions of $100 \mathrm{ng} / \mu \mathrm{l}$ were prepared for experimental use.

A $\sim 1.1 \mathrm{~kb}$ fragment of the rapidly evolving mitochondrial control region was obtained using the PCR primers N1 and D16 (Barrowclough et al. 1999). Amplifications were performed using a PTC 100 thermal cycler (MJ Research). A total 
reaction volume of $50 \mu \mathrm{l}$ was used with the following concentrations: $10 \mathrm{mM}$ Tris $-\mathrm{HCl}$ at $\mathrm{pH}$ 8.3; $50 \mathrm{mM} \mathrm{KCl} ; 0.001 \%$ gelatin; $3.5 \mathrm{mM} \mathrm{MgCl}_{2}$; $100 \mu \mathrm{M}$ for each of the dNTPs; $0.2 \mu \mathrm{m}$ of each primer; $100 \mathrm{ng}$ of template; and $1.5 \mathrm{U}$ AmpliTaq Gold Polymerase (Perkin Elmer). The following parameters were used for amplifications: $12 \mathrm{~min}$ denaturation at $93{ }^{\circ} \mathrm{C}$, followed by 35 cycles of $30 \mathrm{~s}$ at $93{ }^{\circ} \mathrm{C}$, annealing at $50^{\circ} \mathrm{C}$ for $30 \mathrm{~s}$, and elongation at $72{ }^{\circ} \mathrm{C}$ for $1 \mathrm{~min}$. A final $10 \mathrm{~min}$ period of elongation at $72{ }^{\circ} \mathrm{C}$ followed the last cycle. PCR amplification quality was assessed by visualizing $10 \mu \mathrm{l}$ of the product with ethidium bromide on $1 \%$ agarose gels. Successful PCR reactions were cleaned and concentrated by centrifugation dialysis using Microcon 30,000 MW cutoff filters (Amicon Bioseparations). Internal primers D11, D12 and D24 (Barrowclough et al. 1999) were used to generate bidirectional DNA sequence of domain I and II of the control region. The resulting sequence contains $85 \%$ of the variation present in the amplified region. Sequences were generated using ABI Prism Big Dye Terminator Cycle Sequencing chemistry on an automated sequencer (377 DNA Sequencer ABI Prism 377XL Collection Software) located in the Central Services Laboratory at Oregon State University. Ambiguities were resolved by comparing light and heavy-strand sequences or from overlap of different fragments. Sequences were aligned by eye.

Use of avian blood as a DNA source may increase the incidence of nuclear homologue amplifications. Thus, our amplification of a large fragment $(1.1 \mathrm{~Kb})$ of the mitochondrial genome as well as bi-directional sequencing assured that DNA sequences were mitochondrial in origin. Samples containing ambiguous sequence (i.e., double peaks) were excluded from further analyses.

To estimate divergence times among subspecies, a 936 bp portion of the cytochrome $b$ gene was sequenced from five individuals from each subspecies, using the primer set L14996/H16064 (Sorenson et al. 1999) and PCR conditions as indicated previously.

\section{Phylogenetic analyses}

The program PAUP 4.0b10 (Swofford 2002) was used to generate tree topologies representing phylogenetic relationships among control region haplotypes using maximum parsimony, maximum likelihood criteria, and the neighbor joining approach. ML and NP analyses were preformed using 100 replicate heuristic searches with random taxon addition (10 replicates) and tree bisectionreconnection (TBR) branch swapping. Reliability of support for tree nodes was assessed for each method by bootstrap consensus (1000 replicates for MP and NJ, 100 replicates for ML; Felsenstein 1985). The optimum maximum likelihood model of evolution was inferred using the program Modeltest v.3.06 (Posada \& Crandall 1998) which compares different nested models of DNA substitution in a hierarchical hypotheses testing framework. Estimated likelihood values were then analyzed to determine optimum models. This likelihood test was used for nested hypotheses and Akaike information criterion for non-nested hypotheses (Akaike 1974). Maximum likelihood searches were run using the resulting optimal Tamura-Nei (1993) substitution model plus gamma $(\operatorname{TrN}+\mathrm{I}+\mathrm{G})$, gamma shaped parameter 0.0191. Barred owl (Strix varia) sequences were used as an outgroup for each tree.

\section{Nested clade analysis}

We used nested clade analysis (NCA) for the analysis of phylogenetic patterns and to discriminate between recurrent gene flow and historic events (Templeton et al. 1993, 1998). NCA is a statistical method that can detect and test evolutionary processes responsible for the spatial distribution of observed genetic variation. A haplotype tree with $95 \%$ parsimonious connections was constructed using the program TCS 1.13 (Clement et al. 2000). This tree was then converted into a series of nested clades following the nesting rules in Templeton et al. (1987). Ambiguities in the network were resolved using guidelines provided in Templeton and Sing (1993). The program GeoDis 2.0 (Posada et al. 2000) was used to implement the nested cladistic analysis. Two statistics were calculated: clade distance $\left(D_{\mathrm{C}}\right)$ represented the geographical spread of the clade and nested clade distance $\left(D_{\mathrm{N}}\right)$ represented distance of the clade from the geographical center of the nested clade. An interior-tip statistic was also estimated within each nested category as the average interior distance minus the average tip distance. This contrast represents an approximation of the distribution of young versus old haplotypes. Clades 
were tested against their geographical locations using a permutational contingency analysis. The null hypothesis tested is random geographic distribution of all clades within a nested clade.

\section{Molecular clock}

A log-likelihood ratio test ( $\mathrm{TrN}$ model with gamma correction) was used to test the control region sequences for departure from a molecular clock, using the difference in likelihood from a best fit haplotype tree, with and without the molecular clock enforced (Haulsenbeck \& Crandall 1997). We applied the two-cluster test (Takezaki et al. 1995) using the program LINTREE to determine whether individual lineages within spotted owls were evolving in a clock-like fashion. The two-cluster test examines the hypothesis that a molecular clock is in effect along two lineages $\left(b_{A}, b_{B}\right)$ diverging from an interior node of a generated neighbor-joining tree (Tamura-Nei plus gamma distance). The test assesses whether the difference $(\delta)$ in length between daughter lineages is significantly different from zero. The confidence probability $(\mathrm{CP}=1-\mathrm{P})$ is determined with a value of $95 \%$ or higher rejecting the molecular clock for that node. If a molecular clock can be inferred at a node linking two daughter-lineages, a $2 \%$ sequence divergence per million years can be applied to derive dates. There is no fossil record to provide a good calibration for divergence rates in these birds, thus we used a calibration rate of $2 \%$ as has been applied in many other North American avian species assessments (see Brown et al. 1979; Klicka \& Zink 1997; Avise \& Walker 1998). The mean branch length between daughter-lineages $(h)$ is the expected value after correction for the assumption of $2 \%$ per million year divergence (i.e., $1 \%$ along each lineage).

For comparison, cytochrome $b$ divergence times were estimated using Arlequin (version 2.001; Schneider et al. 2000) to generate mean pairwise differences between subspecies which were then used to calculate $\%$ sequence divergence values. The $2 \%$ sequence divergence per million years was then applied to these values to derive dates of divergence.

\section{Population structure and diversity}

Summary statistics within and among breeding areas were derived using ARLEQUIN (version
2.001; Schneider et al. 2000) and included mean ( \pm SD) haplotype diversity (Nei 1987) and mean nucleotide diversity ( \pm SD; Tajima 1983 ; Nei 1987). Pairwise sequence divergence within regions and subspecies was calculated using the methods of Tamura \& Nei (1993). Deviations from the assumptions of neutrality (Kimura 1983) were calculated using Tajima's (1989) $D$-statistic. The $D$-statistic is based on the fact that under the neutral model there is a correlation between estimates of the number of segregating sites and the average number of nucleotide differences. In addition to testing for selection, significant $D$ values can be indicative of factors such as bottlenecks, population increases, or heterogeneity of mutation rates (Tajima 1993; Aris-Brosou \& Excoffier 1996; Tajima 1996). Examination of demographic equilibrium was carried out via comparison of mismatch distributions to a sudden population expansion model (Rogers \& Harpending 1992; Rogers 1995) using the generalized non-linear least-squares approach of Schneider \& Excoffier (1999). Populations that have been stable for a long period of time or are slowly declining have ragged and multimodal distributions whereas populations that have undergone a recent expansion or bottleneck are represented by a single smooth Poisson distribution. DnaSP v.3.5.1 (Rozas \& Rozas 1999) was used to compare results with ARLEQUIN and compute Fu \& Li's (1993) F-test for selective neutrality.

\section{Population differentiation and gene flow}

Hierarchical analysis of molecular variance (AMOVA; Schneider et al. 2000) was used to assess structure within and among subspecies. Total sequence variation was partitioned into within and among subdivision components at three levels: geographically described subspecies, regions, and breeding areas. Significance of $F$ was tested using nonparametric permutations (1000 replications). We calculated mean Tamura-Nei corrected sequence divergence (Tamura $\&$ Nei 1993) and $F_{\mathrm{ST}}$ values (Slatkin 1995) which were correlated with geographic distance using a Mantel test (Mantel 1967) among all breeding areas. Finally, estimates of gene flow, expressed as the estimated number of female migrants per generation $\left(N_{\mathrm{ef}} m_{\mathrm{f}}\right.$, where $N_{\mathrm{ef}}$ is the genetic effective population size of females and $m_{\mathrm{f}}$ is the female migration rate per generation) 
were derived from $F_{\mathrm{ST}}=1 /\left(1+2 N_{\mathrm{ef}} m_{\mathrm{f}}\right)$ (Slatkin 1991) as a means of relative comparison among regions and subspecies. A sequential Bonferroni test was used to estimate $p$ for multiple comparisons of $F_{\mathrm{ST}}$ (Rice 1989). Maximum likelihood estimates of $N_{\text {ef }} m_{\mathrm{f}}$ were also calculated in MIGRATE v.1.6.5 (Beerli \& Felsenstein 1999, 2001). This Markov Chain Monte Carlo (MCMC) approach estimates the effective number of migrants (haplotypes) exchanged between sampling areas each generation over the entire coalescent time. Results account for unequal migration rates and different population sizes and assumed recombination or selection had not occurred. Although these estimates may not be accurate measures of movement among breeding areas, their relative estimation provides insight into population isolation.

\section{Results}

\section{Sequence diversity}

Control region sequences were generated from a large $1.1 \mathrm{~kb}$ fragment obtained from primers located within the flanking tRNA fragment and from a highly conserved region within the spotted owl control region. The pattern of variability across sequences paralleled that reported in previous spotted owl mtDNA analyses (Barrowclough et al. 1999). Therefore, we assumed sequences were mitochondrial in origin, rather than nuclear. To verify the absence of heteroplasmic individuals, clone libraries were generated from two spotted owl samples. Ten individual clones were sequenced from each library and in each case only one haplotype was recovered.

Among 213 individuals sampled in 30 breeding areas, we found 63 unique haplotypes (approximately one for every three individuals sequenced) in a $522 \mathrm{bp}$ portion that spanned domain I and a portion of domain II of the avian mitochondrial control region (Table 1; Baker and Marshall 1997). Sequences resulted in identification of 59 transitions, 2 transversions, and 2 deletions occurring between base pairs 194 and 700 (Table 1). Among traditional geographically-defined subspecies, there were 29 distinct haplotypes in northern spotted owls, 11 in California spotted owls, and 23 in Mexican spotted owls. Two of the three most widespread haplotypes (Quin $3, \mathrm{n}=32$ birds; and Wspr5, $\mathrm{n}=25$ birds) were found throughout the range of northern spotted owls. The other common haplotype, Lass 1, was the most common California spotted owl haplotype and was found in 31 birds within the range of northern and California spotted owls.

\section{Relationships among subspecies}

Phylogenetic analyses based on aligned control region sequences of unique haplotypes indicated similar topologies for all methods of tree inference. For maximum parsimony analyses, 4270 most parsimonius trees were found, each comprised of 114 steps based on 43 parsimony-informative characters. Maximum likelihood bootstrap analyses yielded a $-\ln$ likelihood score of 1384.51, allowing for rate heterogeneity among codon positions and using distances generated with the Tamura-Nei substitution model. The neighbor joining tree, using the Tamura-Nei plus gamma model, indicated a northern spotted owl clade (bs $=85$ ) and a California and Mexican spotted owl clade: (Figure 2). The northern clade was basal to the California spotted owl and Mexican spotted owl clade and contained only haplotypes identified as northern spotted owls. The California spotted owl/Mexican spotted owl clade further segregated into California and Mexican clades, although with weak support. California spotted owls formed a sister clade to the Mexican spotted owl clade and also contained haplotypes that, based on geographic location, would be identified as northern spotted owls. Mexican spotted owls formed a monophyletic group, which was reciprocally monophyletic in two of the three methods. However, depending on the inference method used, the Mexican group containing the Pimal haplotype segregated unstably between the California and Mexican clades. There was weak support for structure within the three clades which did not appear to correspond to any geographic predictions.

Haplotypes of northern spotted owls and Mexican spotted owls were not found outside of their predicted range (Table 1). However, California spotted owl haplotypes were found in the traditional geographic ranges of both northern and Mexican spotted owls. California spotted owl haplotypes were found in $15 / 116(12.9 \%)$ owls that 


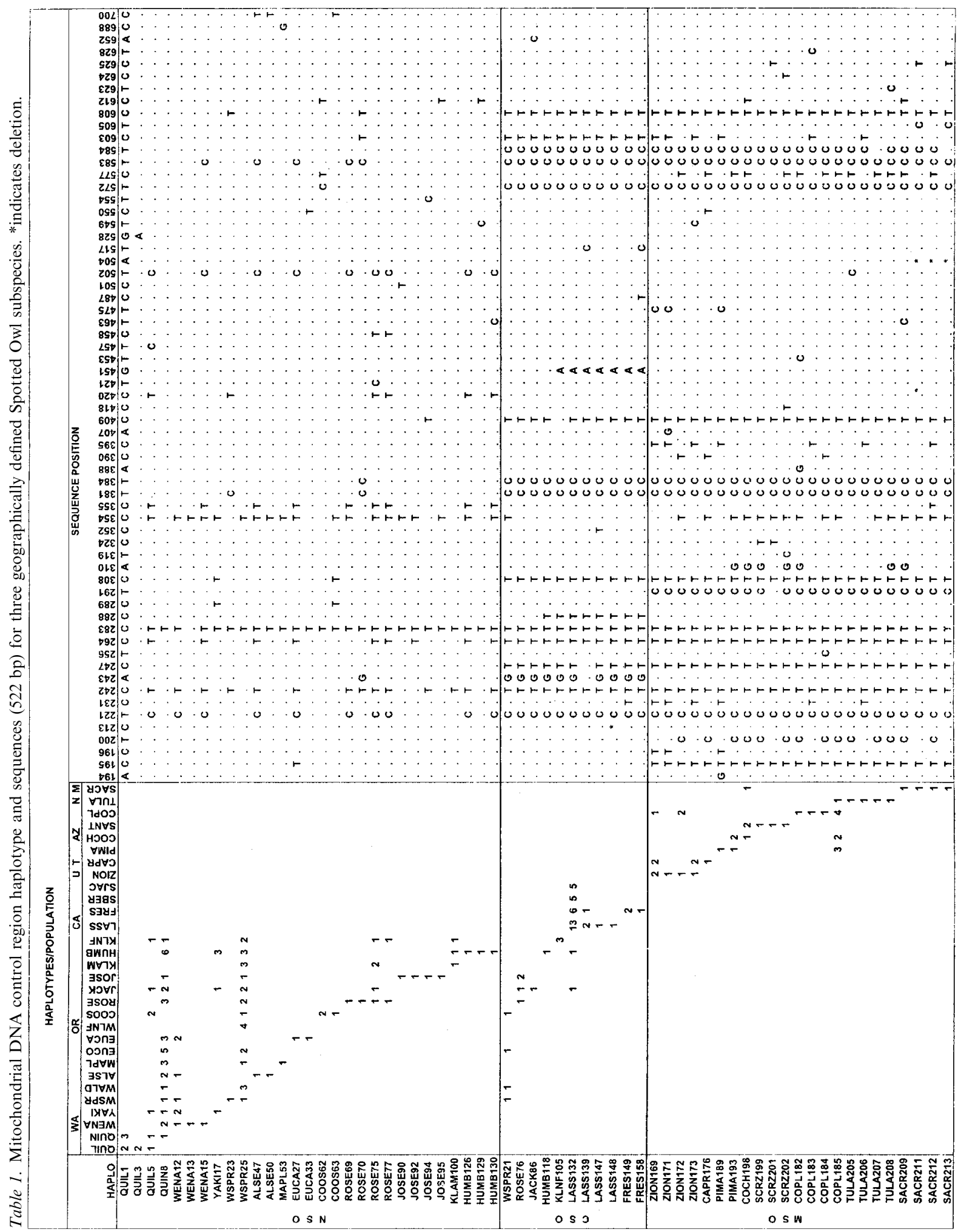




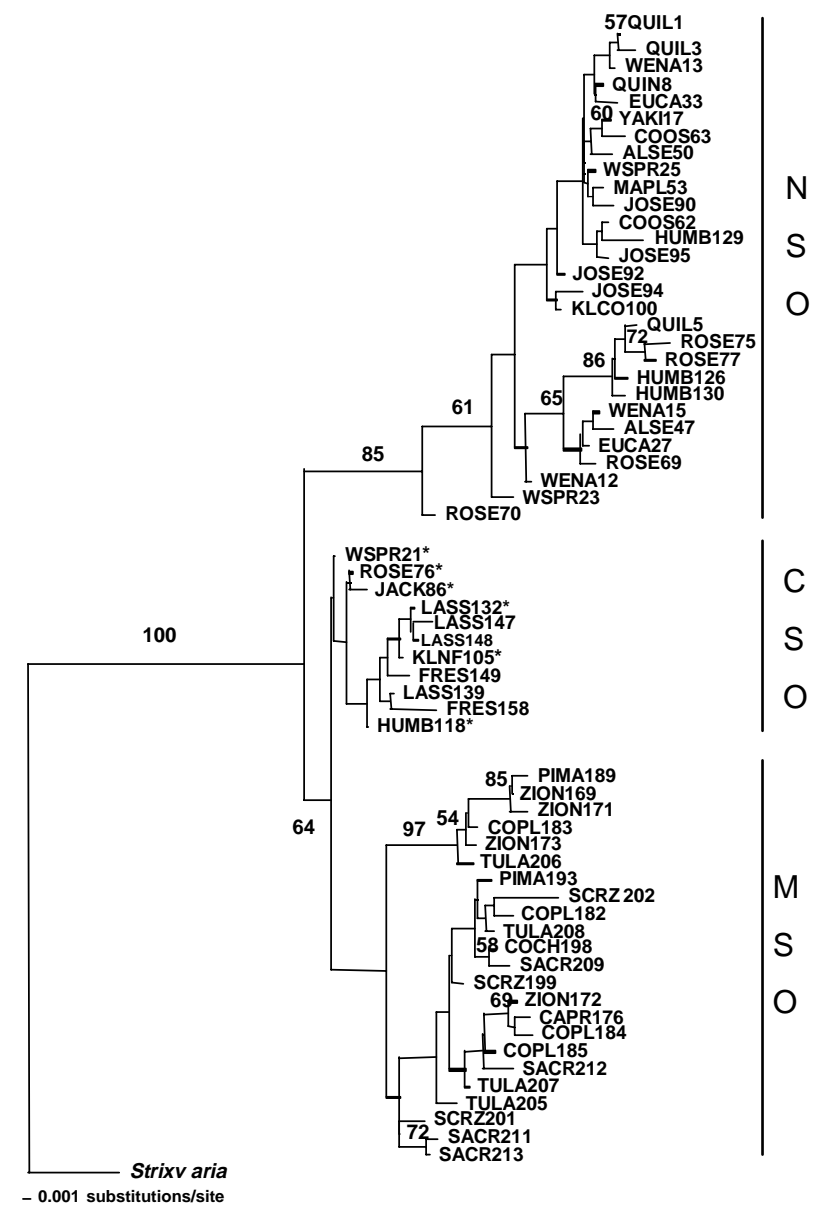

Figure 2. Neighbor-joining tree for spotted owls based upon sequences (522 bp) in domains I and II of the mitochondrial control region. Bootstrap values of 50 or more are reported. Asterisks $(*)$ indicate California spotted owl (CSO) haplotypes found in the range of northern spotted owls (NSO). MSO = Mexican spotted owl.

occupied the traditional geographic range of the northern spotted owl (Table 2). These haplotypes were most common among owls in the Klamath Mountains (12/59 birds; 20.3\%), with a single haplotype (Wsprl) occurring as far north as Waldport, Linn Co., OR, in the Coast range and the Warm Springs Indian Reservation, Jefferson Co., OR, in the Cascade range. This may indicate the presence of a stable northern spotted owl/ California spotted owl hybrid zone throughout the Klamath region with the Wsprl haplotype representing a deep penetration arising from a rare introgression or founder event.

\section{Haplotype network and nested design}

Nested clade analyses resulted in a maximum number of nine mutational steps between haplo- types that allowed parsimonious connections at a probability equal or greater than $95 \%$ (Figure 3). More than one most parsimonious solution was possible, as indicated by the presence of loops in the resulting cladogram. Thus, ambiguities were addressed as recommended by Templeton et al. (1987). Ambiguities which could not be resolved were included in the next nesting level.

The cladogram nesting procedure resulted in three distinct level 4 clades. Clade 4-1 was composed entirely of haplotypes identified as northern spotted owl and was separated from the remaining cladogram by seven mutational steps. Clade 4-3 was separated from Clade 4-2 by three mutational steps and contained only Mexican spotted owl haplotypes. Clade 4-2, contained all California spotted owl haplotypes in addition to haplotypes that geographically would be considered northern 
Table 2. Occurrence of northern and California spotted owl haplotypes found in the traditional geographic range of northern spotted owls

\begin{tabular}{|c|c|c|c|}
\hline \multirow[t]{2}{*}{ Region } & \multirow[t]{2}{*}{ Breeding area } & \multicolumn{2}{|l|}{ Subspecies } \\
\hline & & Northern spotted owl & California spotted owl \\
\hline \multirow[t]{3}{*}{ Olympic Range } & & 10 & - \\
\hline & Quilcene, WA & 5 & - \\
\hline & Quinault, WA & 5 & - \\
\hline \multirow[t]{6}{*}{ Cascade Range } & & 29 & 1 \\
\hline & Wenatchee, WA & 5 & - \\
\hline & Yakima, WA & 5 & - \\
\hline & Warm Springs, OR & 4 & 1 \\
\hline & Eugene BLM, OR & 10 & - \\
\hline & Willamette NF, OR & 5 & - \\
\hline \multirow[t]{5}{*}{ Coast Range } & & 18 & 2 \\
\hline & Waldport, OR & 4 & 1 \\
\hline & Alsea, OR & 5 & - \\
\hline & Mapleton, OR & 5 & - \\
\hline & Eugene Coast, OR & 4 & 1 \\
\hline \multirow[t]{8}{*}{ Klamath Region } & & 59 & 12 \\
\hline & Coos Bay, OR & 6 & 1 \\
\hline & Roseburg, OR & 9 & 1 \\
\hline & Josephine Co., OR & 6 & 2 \\
\hline & Klamath Co., OR & 6 & - \\
\hline & Jackson Co., OR & 7 & 3 \\
\hline & Humboldt Co., CA & 18 & 2 \\
\hline & Klamath NF, OR/CA & 7 & 3 \\
\hline Total & & 116 & 15 \\
\hline
\end{tabular}

Values represent the number of birds in each region and breeding area that contain haplotypes from each subspecies.

Table 3. Inference chain for nested geographical analysis of spotted owl cladograms using the inference key given in Templeton (1998)

\begin{tabular}{lll}
\hline Clades nested in & Inference chain/populations involved & Inference \\
\hline $1-1$ & $1-2-11-17-4-9-10 ;$ Quil, Quin, Wena & AF \\
$1-11$ & $1-2-3-4-9-10 ;$ NO; Jack, Klnf, Lass, Fres & IS \\
$2-1$ & $1-2-11-12-13$; Quil, Quin, Wena, Wspr, Jose, Mapl & LDC \\
$2-2$ & $1-2-3-4-9$ NO; Quil, Wena, Euca, Alse, Rose, Humb & PF \\
$2-4$ & $1-2-3-4-9$ NO; Quin, Euca, Coos, Jose, Humb & PF \\
$2-9$ & $1-2-3-4-9-10 ;$ Zion, Capr, Cocc, Tula, Sacr & AF \\
$3-4$ & $1-2-11-12-13-14$ YES & LDC \\
$3-7$ & $1-2-11-17-4-9-10$ YES & AF \\
$4-2$ & $1-2-11-17-4$ NO & IBD \\
$4-3$ & $1-2-11-12$ NO/1-2-11-17 & CRE/IO \\
Entire cladogram & $1-2-3-4$ NO & IBD \\
\hline
\end{tabular}

spotted owl and Mexican spotted owl. This cladogram showed little variation from the haplotype structure presented in the neighbor-joining tree (Figure 2). The Mexican spotted owl haplotypes from the Pimal clade, which grouped with clade 42, also segregated with the California spotted owl clade in the neighbor-joining tree under certain inference conditions (Table 3). In one variation, 
692

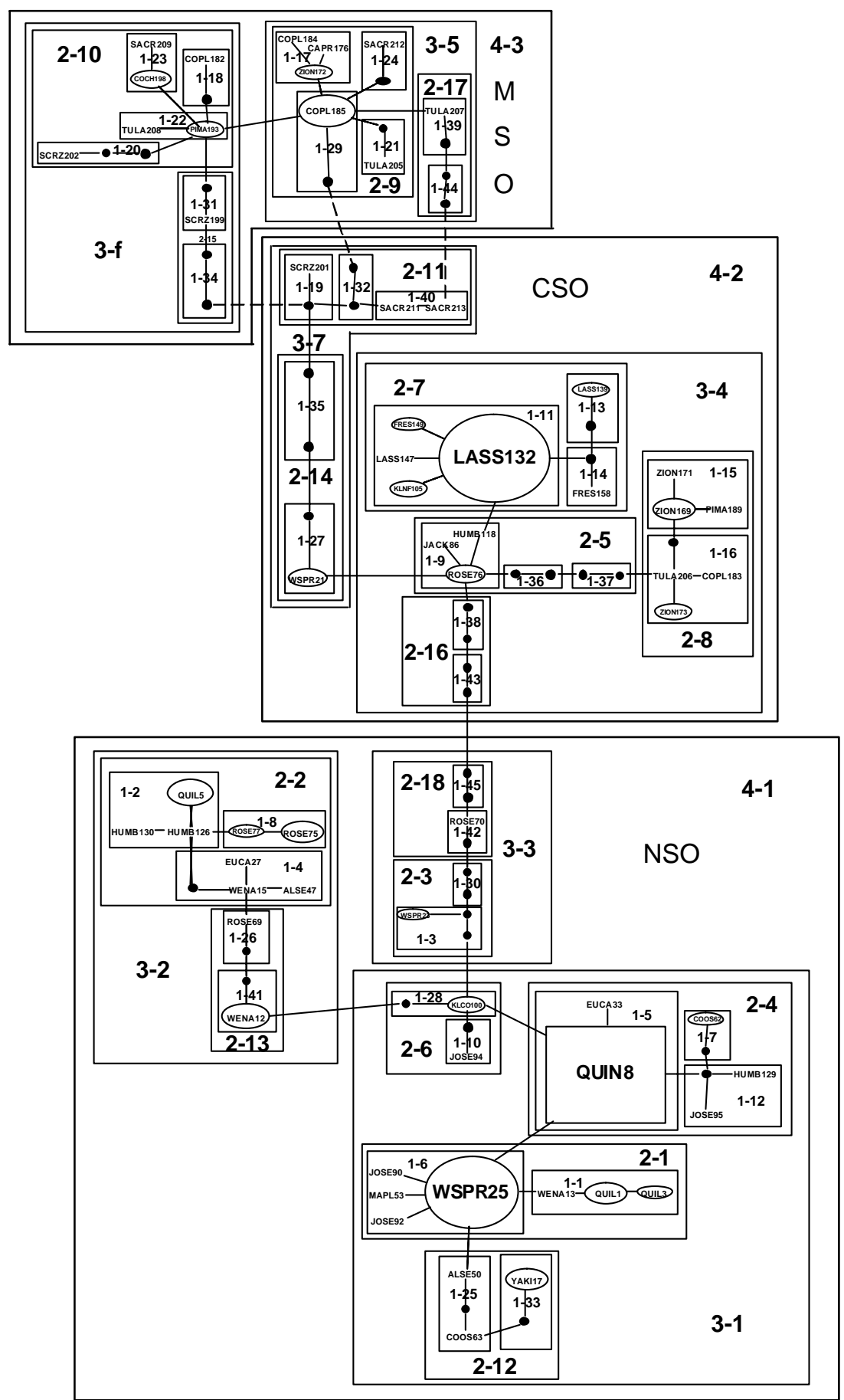

Figure 3. Minimum-spanning haplotype network nested following the procedures of Templeton et al. (1987). Connections $<9$ substitutions have a 0.95 probability of being parsimonious. Zeros indicate ancestral haplotypes that were not sampled. Solid line represents a single mutational step which connects two haplotype states. Dashed lines represent a connection for which parsimony is not supported at the $95 \%$ level. The level of the nested clade is given: 1-x for 1-step clades, 2-x for 2-step clades, etc. 
Mexican spotted owl haplotypes from Santa Cruz, $\mathrm{AZ}$, and the Sacramento Mts, NM segregated into clade 4-2. While this association was not present in the neighbor-joining tree, there was little bootstrap support for their segregation. Only two Mexican spotted owl breeding areas from distinctly separate parts of the range (Capitol Reef National Park, UT and Cochise Co., AZ) did not contain haplotypes which associated with the California spotted owl group in the NCA. As determined by permutational contingency analyses, geographic structure was significant in two of the 1-step clades (1-1, 1-11), three of the 2-step clades (2-1, 2-2, 2-9), the higher level clades 3-4, 3-7, 4-2, and the entire cladogram 5-1 (Table 4). Quin8 was determined to be the oldest haplotype observed from frequency and nesting structure. It contained samples from throughout the traditional range of the northern spotted owl.

The log-likelihood ratio test (lrt) of the best-fit tree, with and without a molecular clock enforced, rejected the simpler (clock-like) tree on a significance level of $5 \%$ (1447.08 versus 1384.51 , $1 \mathrm{rt}=62.57, \quad P<0.01, \quad \mathrm{df}=63)$ suggesting the overall spotted owl control region was not evolving in a clock-like manner. However, 37 of 62 nodes of the constructed neighbor-joining tree contained daughter lineages evolving in a manner consistent with a molecular clock. Using the twocluster test and a calibration rate of $2 \%$ per million years, approximate dates can be inferred at each of the 37 nodes and estimated separation dates among the subspecies can be established: northern spotted owl versus California spotted owl/Mexican spotted owl (1.9 mya), California spotted owl versus Mexican spotted owl (1 mya). Calculation of divergence times using cytochrome $b$ data suggested more recent divergence times between the subspecies: NSO versus MSO/CSO (115,000125,000 yrs), CSO versus MSO (15,000 yrs).

\section{Population structure and variation}

Overall levels of sequence variation were typical of those found in other avian studies (Table 5, Baker and Marshall 1997). Haplotype diversity was high within breeding areas with the exceptions of northern spotted owls in the Willamette National Forest and all California spotted owls. Among all owls, mean genetic variation within breeding areas (nucleotide diversity, $\pi$ ) was $0.024 \pm 0.012$,
Table 4. Permutational chi-square probabilities for geographical structure of spotted owl clades identified in Figures 2 and 3 from 1000 resamples. Clades with probability values less than 0.05 suggest significant geographical structure. Clades with no genetic or geographical variation are excluded

\begin{tabular}{|c|c|c|}
\hline \multirow[t]{2}{*}{ Clade } & \multicolumn{2}{|c|}{ Permutational } \\
\hline & Chi-square statistic & Probability \\
\hline $1-1$ & 10.40 & $0.04 *$ \\
\hline $1-2$ & 8.00 & 0.87 \\
\hline $1-4$ & 6.00 & 1.00 \\
\hline $1-5$ & 5.14 & 0.77 \\
\hline $1-6$ & 31.36 & 0.57 \\
\hline $1-9$ & 8.25 & 0.37 \\
\hline $1-11$ & 47.14 & $0.02 *$ \\
\hline $1-12$ & 2.00 & 1.00 \\
\hline $1-15$ & 8.40 & 0.53 \\
\hline $1-16$ & 10.00 & 0.21 \\
\hline $1-17$ & 5.56 & 0.69 \\
\hline $1-22$ & 4.00 & 0.54 \\
\hline $1-23$ & 1.88 & 1.00 \\
\hline $1-25$ & 2.00 & 1.00 \\
\hline $2-1$ & 35.00 & $0.00^{*}$ \\
\hline $2-2$ & 30.00 & $0.04 *$ \\
\hline $2-4$ & 50.68 & 0.06 \\
\hline $2-6$ & 4.00 & 1.00 \\
\hline $2-7$ & 5.17 & 0.78 \\
\hline $2-8$ & 2.74 & 0.90 \\
\hline $2-9$ & 32.74 & $0.03^{*}$ \\
\hline $2-10$ & 20.90 & 0.17 \\
\hline $2-11$ & 3.00 & 0.33 \\
\hline $2-12$ & 6.00 & 0.29 \\
\hline $2-13$ & 8.00 & 0.48 \\
\hline $3-1$ & 52.61 & 0.41 \\
\hline $3-2$ & 12.61 & 0.55 \\
\hline $3-3$ & 2.00 & 1.00 \\
\hline $3-4$ & 106.67 & $0.00^{*}$ \\
\hline $3-5$ & 5.29 & 0.60 \\
\hline $3-6$ & 2.18 & 1.00 \\
\hline $3-7$ & 6.00 & 0.45 \\
\hline $4-1$ & 37.02 & 0.31 \\
\hline $4-2$ & 66.00 & $0.00^{*}$ \\
\hline $4-3$ & 12.33 & 0.06 \\
\hline Entire cladogram & 292.09 & $0.00^{*}$ \\
\hline
\end{tabular}

although it varied widely. The highest nucleotide diversity occurred in the Klamath Mountains. The lowest nucleotide diversity occurred among California spotted owls; northern spotted owls from Mapleton, OR, and the Willamette National Forest, OR; and Mexican spotted owls from 


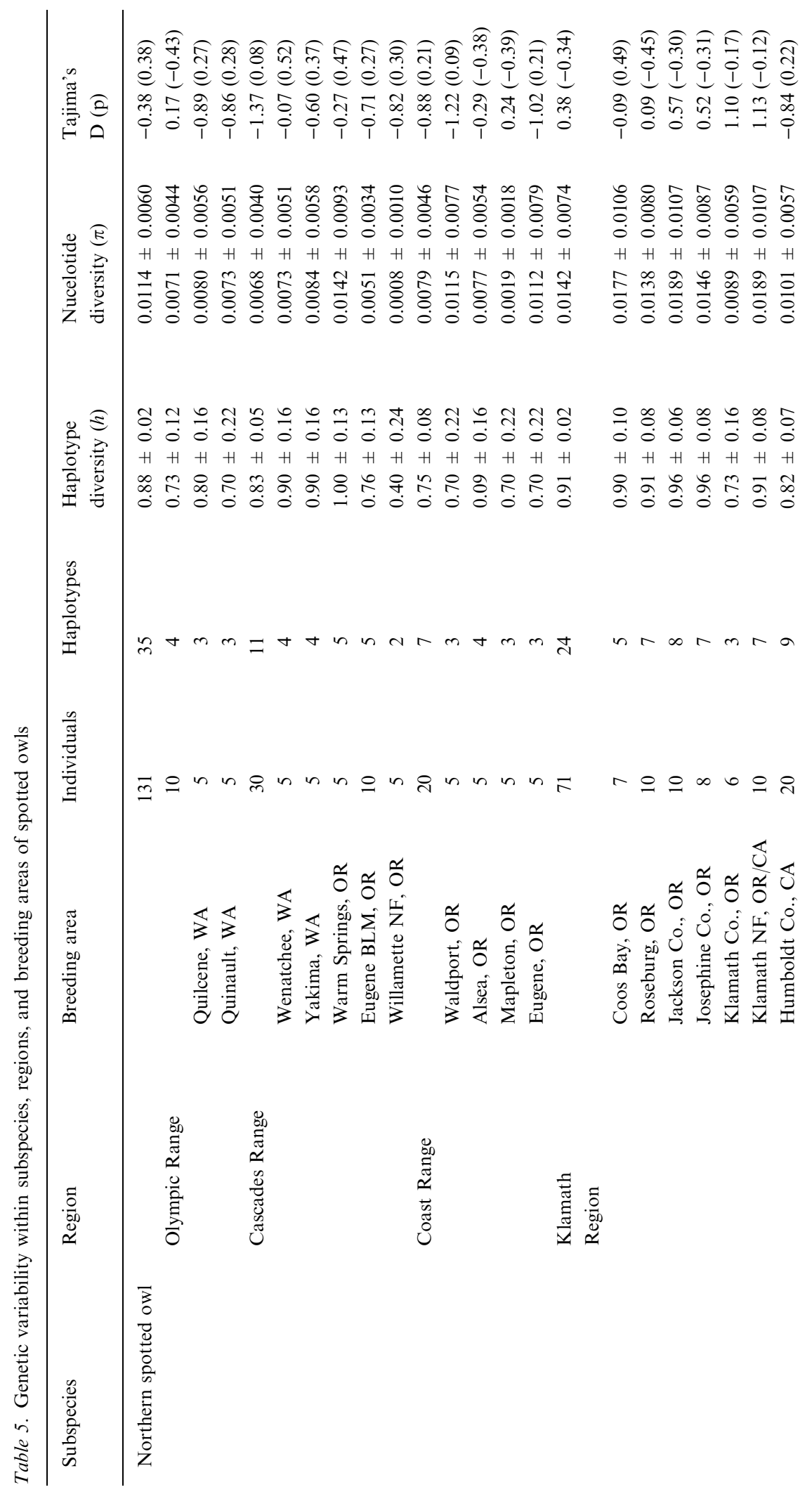




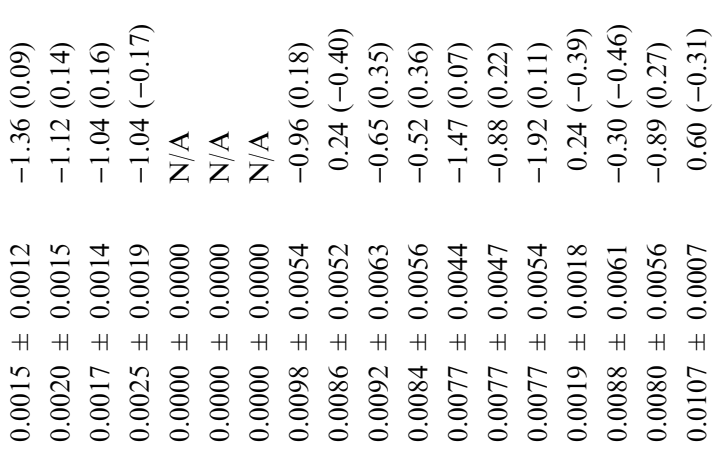

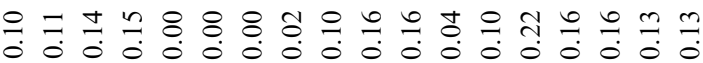

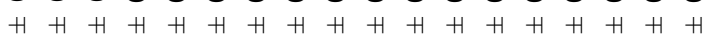

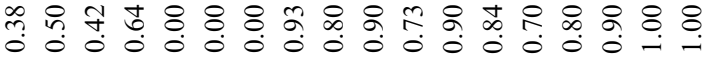

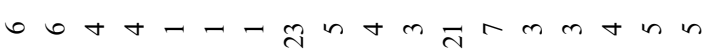

드소으의 年

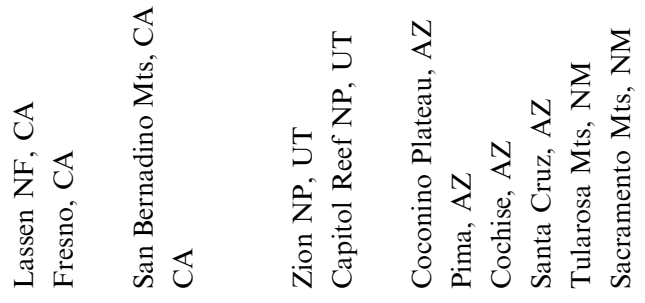

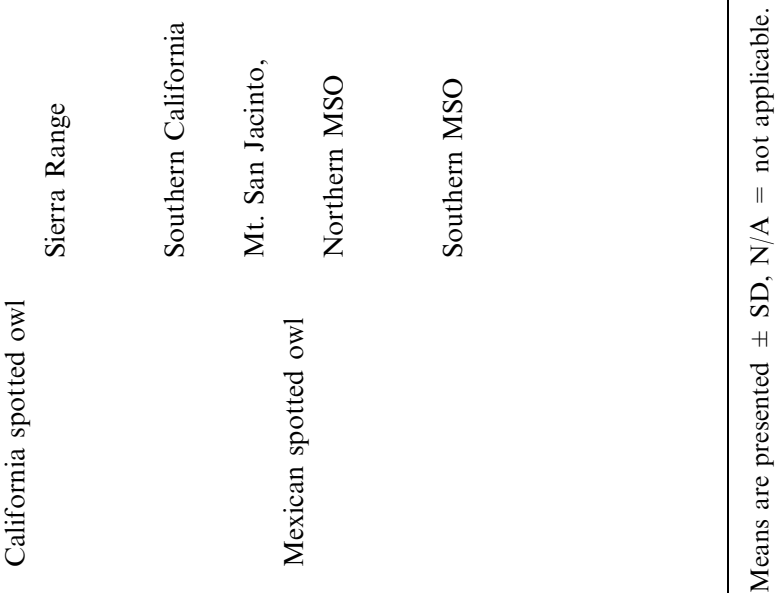


Cochise, AZ. A Tajima's test on all groupings, assuming equilibrium and unstructured populations, resulted in values of $D$ that did not significantly vary from expectations of the neutral mutation model. Thus, we cannot reject the hypothesis that sequence variation is selectively neutral or that populations are stable or expanding. Although not significant, $D$ values for northern spotted owls in the Oregon Cascades and in the Coast Range near Waldport, California spotted owls, and southern Mexican spotted owls were quite negative. Overall $D$ for spotted owls was 0.16 $(P=-0.42)$.

Mismatch distributions of pairwise substitution differences between pairs of haplotypes were plotted for spotted owl subspecies grouped as they have been traditionally defined geographically (Figure 1). None of the analyses resulted in a unimodal distribution (Figure 4) and all resulted in non-significant $(P>0.10) \mathrm{Fu} \& \mathrm{Li}$ F-statistics (northern spotted owl $=-0.44$, California spotted owl $=-0.83$, Mexican spotted owl $=-1.90$ ). Thus, we found no evidence for recent or extensive population growth.

\section{Population differentiation and gene flow}

Hierarchical comparisons of genetic variation within groups to among groups was investigated via AMOVA (Table 6). Significant variation was found among regions in each geographically-defined subspecies. Further, in all comparisons except between geographically-defined subspecies, most variation was attributed to variation among individuals within breeding areas.

This included significant differentiation $(56.2 \%)$ within breeding areas of Mexican spotted owls. Maximum likelihood estimates of gene flow among suggested little genetic exchange among geographically-defined subspecies with the exception of from California spotted owls to northern spotted owls and a small amount from Mexican to California spotted owls (Table 7).

A Mantel test suggested a significant relationship between geographic distance and pairwise $F_{\mathrm{ST}}$ values when all breeding areas were compared $(r=0.74, P<0.01)$ and within Mexican spotted owl breeding areas $(r=0.54, P<0.01$; Table 8$)$. However, there was not a significant relationship within northern or California spotted owl breeding areas $(r=0.15$ and -0.98 , respectively). Compar-
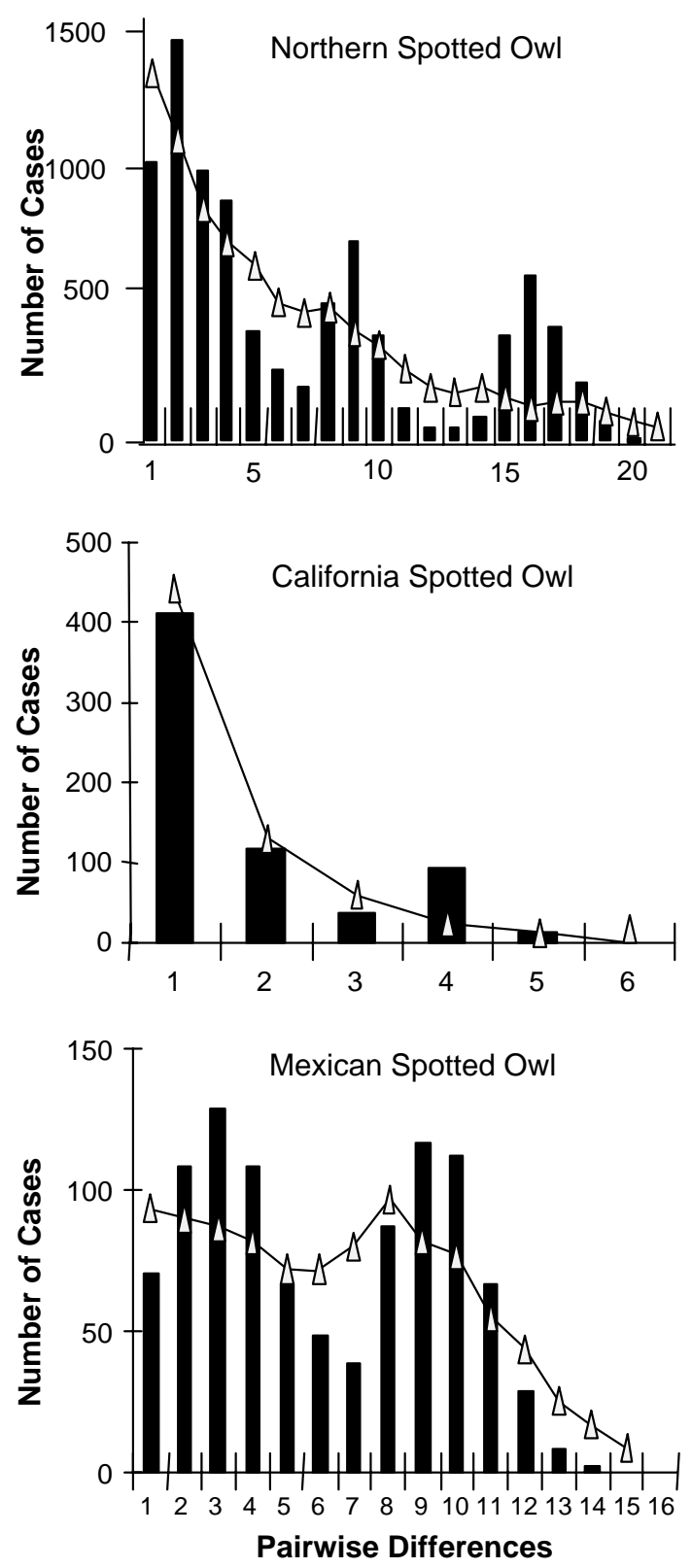

Figure 4. Observed mismatch distributions for the number of differences among mitochondrial control region haplotypes in spotted owls. Distributions presented represent geographical (i.e., not phylogenetic) groupings of subspecies. Triangles with connecting lines indicate expected distribution for a sudden population expansion (Rogers \& Harpending 1992; Rogers 1995).

ison of pairwise $F_{\mathrm{ST}}$ values among all breeding areas within geographically-defined subspecies indicated no significant differentiation (all $P<0.05$ ), except for one comparison in northern spotted owls and in 3 of 28 paired comparisons 
Table 6. Analysis of molecular variance (AMOVA) of control region mitochondrial DNA haplotypes within and among the traditional ranges of three geographically-defined spotted owl subspecies

\begin{tabular}{|c|c|c|c|c|c|}
\hline \multirow{2}{*}{ Source of variation } & \multicolumn{3}{|c|}{ Variance components } & \multirow[b]{2}{*}{$F$} & \multirow[b]{2}{*}{$P \leq$} \\
\hline & d.f. & Variance & $\%$ of total & & \\
\hline \multicolumn{6}{|l|}{ Spotted owls } \\
\hline Among subspecies & 2 & 5.74 & 69.32 & $F_{\mathrm{CT}}=0.69$ & 0.00 \\
\hline Among breeding areas within subspecies & 27 & 0.18 & 2.14 & $F_{\mathrm{SC}}=0.07$ & 0.01 \\
\hline Among individuals within subspecies & 184 & 2.36 & 28.53 & $F_{\mathrm{ST}}=0.71$ & 0.00 \\
\hline Among subspecies & 2 & 5.27 & 67.16 & $F_{\mathrm{CT}}=0.67$ & 0.00 \\
\hline Among regions within subspecies & 5 & 0.30 & 3.76 & $F_{\mathrm{SC}}=0.11$ & 0.00 \\
\hline Among individuals within regions & 205 & 2.28 & 29.08 & $F_{\mathrm{ST}}=0.71$ & 0.00 \\
\hline \multicolumn{6}{|l|}{ Northern spotted owls } \\
\hline Among regional groups & 3 & 0.15 & 4.68 & $F_{\mathrm{CT}}=0.05$ & 0.01 \\
\hline Among breeding areas within regional groups & 14 & -0.07 & -2.19 & $F_{\mathrm{SC}}=-0.02$ & 0.62 \\
\hline Among individuals within breeding areas & 113 & 3.04 & 97.51 & $F_{\mathrm{ST}}=0.02$ & 0.31 \\
\hline \multicolumn{6}{|l|}{ California spotted owls } \\
\hline Among regional groups & 1 & 0.01 & 3.46 & $F_{\mathrm{CT}}=0.03$ & 0.00 \\
\hline Among breeding areas within regional groups & 2 & -0.02 & -5.58 & $F_{\mathrm{SC}}=-0.06$ & 0.48 \\
\hline Among individuals within breeding areas & 33 & 0.37 & 102.12 & $F_{\mathrm{ST}}=-0.02$ & 0.66 \\
\hline \multicolumn{6}{|l|}{ Mexican spotted owls } \\
\hline Among regional groups & 1 & 1.63 & 44.39 & $F_{\mathrm{CT}}=0.44$ & 0.00 \\
\hline Among breeding areas within regional groups & 6 & -0.02 & -0.62 & $F_{\mathrm{SC}}=-0.01$ & 0.51 \\
\hline Among individuals within breeding areas & 38 & 2.06 & 56.23 & $F_{\mathrm{ST}}=0.44$ & .00 \\
\hline
\end{tabular}

Table 7. Maximum likelihood estimates of asymmetric migration $\left(2 N_{\mathrm{ef}} m_{\mathrm{f}}\right)$ among geographically-defined spotted owl subspecies

\begin{tabular}{llll}
\hline \multirow{2}{*}{ To } & From & & \\
\cline { 2 - 4 } & Northern spotted owl & California spotted owl & Mexican spotted owl \\
\hline Northern spotted owl & - & 1.6 & $6.9 \times 10^{-10}$ \\
California spotted owl & $2.7 \times 10^{-16}$ & - & 0.07 \\
Mexican spotted owl & $2.3 \times 10^{-15}$ & $8.4 \times 10^{-10}$ & - \\
\hline
\end{tabular}

among Mexican spotted owl breeding areas (Table 8). However, comparisons between breeding areas of different geographically-defined subspecies indicated significant differentiation in $82 \%$ of northern versus California spotted owl comparisons, $72 \%$ of California versus Mexican spotted owl comparisons, and $70 \%$ of northern versus Mexican spotted owl comparisons. All comparisons of $F_{\mathrm{ST}}$ between regions of different geographically-defined subspecies were significantly different (Table 9). Within subspecies, Mexican spotted owls from the northern portion of their range (i.e., Utah) were significantly different from Mexican spotted owls in more southern regions. Subsequent estimates of gene flow between all regions within subspecies, while most valuable in a comparative sense only, exceeded Wright's (1931) recommendation of one migrant per generation with the exception of Mexican spotted owls where $\mathrm{Nm}$ between regions was 0.55 (Table 9).

\section{Discussion}

Results from this work suggest a different view of spotted owl genetic structure than has previously been reported. We investigated these issues to further resolve spotted owl genetic structure, integrating a complex history of range fluctuation, introgression, and vicariance biogeography (Avise 
Table 9. Estimates of pairwise population differentiation $\left(F_{\mathrm{ST}}\right.$; below diagonal) and gene flow $(\mathrm{Nm}$; above diagonal) within and among regional populations of geographically-defined northern spotted owls (NSO), California spotted owls (CSO), and Mexican spotted owls (MSO)

\begin{tabular}{lcccccccc}
\hline Region & 1 & 2 & 3 & 4 & 5 & 6 & 7 & 8 \\
\hline 1. NSO - Olympic & - & 4.74 & 3.66 & 5.58 & 0.02 & 0.03 & 0.03 & 0.03 \\
2. NSO - Cascades & 0.10 & - & inf & inf & 0.04 & 0.06 & 0.04 & 0.05 \\
3. NSO - Coast Range & 0.12 & -0.03 & - & inf & 0.06 & 0.08 & 0.05 & 0.06 \\
4. NSO - Klamath & 0.08 & -0.00 & -0.02 & - & 0.19 & 0.23 & 0.11 & 0.13 \\
5. CSO - Northern & $0.96^{*}$ & $0.92^{*}$ & $0.90^{*}$ & $0.73^{*}$ & - & 9449 & 0.13 & 0.13 \\
6. CSO - Southern & $0.94^{*}$ & $0.90^{*}$ & $0.86^{*}$ & $0.68^{*}$ & 0.00 & - & 0.19 & 0.17 \\
7. MSO - Northern & $0.94^{*}$ & $0.93^{*}$ & $0.90^{*}$ & $0.82^{*}$ & $0.80^{*}$ & $0.73^{*}$ & - & 0.55 \\
8. MSO - Southern & $0.94^{*}$ & $0.91^{*}$ & $0.90^{*}$ & $0.80^{*}$ & $0.79^{*}$ & $0.74^{*}$ & $0.47^{*}$ & - \\
\hline
\end{tabular}

Boxes indicate geographical (i.e., traditional) subspecies delineation. * Indicates significant population differentiation $(P<0.05)$.

2000). This clarification will help resolve current debates regarding ESA listing of various subspecies and populations of the spotted owl.

\section{Relationships among subspecies}

Analyses at the subspecies level revealed several important changes in our understanding of these groups. For the three geographically-defined subspecies, historic events such as allopatric fragmentation and long distance colonization appeared to be predominant processes for shaping clade structure. Among subspecies, control region and cytochrome $b$ divergence times suggest a Pleistocene origin with northern spotted owls. Control region dates would put this initial divergence at 1.9 mya, while cytochrome $b$ places the split at a more recent 150,000 yrs. The cytochrome $b$ dates should reflect a more accurate timeframe due to the clock-like manner of the gene, however both methods reinforce the initial divergence occurring between the Northern Spotted Owls and California and Mexican Spotted Owls, with the split between California and Mexican Spotted Owls coming at a much later date.

The original divergence between northern and California spotted owls is perplexing as their current ranges are adjacent or overlapping and there appears to be more potential geographic or habitat barriers to dispersal within these subspecies ranges than between them. Further, the most notable potential habitat barriers within subspecies (e.g., Puget Sound, WA, or Willamette Valley, OR) have been breached numerous times indicating spotted owls are effective dispersers (Forsman et al. 2002).
Insight into the radiation of northern and California spotted owls may be gained by examination of phylogeographic patterns of other species in the Klamath region, the area in which a zone of hybridization has occurred on the northsouth border between northern and California spotted owls. This region is also the north-south border and often the hybrid zone between numerous other plant and animal subspecies or species (reviewed in Soltis et al. 1997). Multiple hypotheses have been proposed to explain this apparent phenomenon that occurred before and after Pleistocene glaciation. The north-south recolonization hypothesis (Soltis et al. 1997), where well separated northern and southern populations undergo genotype fixation followed by secondary contact, may best explain the structure observed between northern and California spotted owls. For example, clade 4-1, which represents northern spotted owls, indicates strong evolutionary clustering and is separated from the remaining cladogram by a long branch length with missing intermediates. This structure implies past fragmentation which may support the unglaciated northern refugia theory in which northern and southern haplotypes became fixed due to isolation by glaciation (Avise 1994). Following glaciation, a continuous geographic range was reestablished, but with the genetic discontinuity now present.

An alternative hypothesis is that deep phylogeographic breaks can occur in a continuously dispersing species if individual dispersal distances and/or population sizes are low (Irwin 2002). This would result from low dispersal and modes of mtDNA inheritance. This hypothesis could be true 
for all three subspecies of spotted owls given their demography and relatively short dispersal distances (Forsman et al. 2002) and would not exclude elements of hypotheses introduced above.

Somewhat different processes may have shaped the relationship between California and Mexican spotted owls. Their overall structure appears to reflect repeated post-glacial range expansion by long-distance colonization (e.g., clade 3-4) on the part of California spotted owls, followed by fragmentation and secondary contact with Mexican spotted owls. Clade 3-7 appears to be influenced by fragmentation events whereas clade $2-11$ is at the extreme eastern end of the species distribution and a great distance from the geographic center of the clade.

The significance of Pleistocene glaciation on avian speciation and population structure is currently under debate. Our results support the idea that biogeographic factors during the Pleistocene promoted substantial microevolutionary genetic diversification in birds (Avise \& Walker 1998). We do not know the pre-Pleistocene history of the species and cannot speculate on its significance. Therefore, we cannot evaluate the hypothesis of Klicka \& Zink (1997) that the Pleistocene was not the prime force in bird speciation and subsequent structure.

Given the range overlap and lack of phenotypic differences among spotted owl subspecies, it is not surprising that we found California spotted owl haplotypes in the geographic range of northern spotted owls. These results are supported by previous genetic studies by Barrowclough et al. (1999) and Haig et al. (2001). Historically, the Pit River (east of Redding, CA) is considered the subspecies boundary, although there has always been an assumption that there was mixing in this contact zone and that reproductive isolation was not a criteria for defining these subspecies (Verner et al. 1992). Our study supports the presence of a hybrid zone in the Klamath region of southern Oregon and northern California. This zone is narrow relative to owl dispersal rates $(\sigma)$, yet does not appear to be situated on a sharp ecotone. Since these subspecies have been in contact for some time, it appears that selection against hybrids is occurring, which would prevent dispersal from increasing the width of the zone. Thus, this stable hybrid zone appears to be a tension zone that remains narrow due to a balance between selection and dispersal.
Although apparently a widespread phenomena and resulting in viable intraspecific hybrids, the genetic effect of intraspecific hybridization is not clear for spotted owls. There is no evidence that Haldane's rule (1922) has taken effect. That is, there have been no observations of reduced fitness in the heterogametic sex (females) in the areas of widespread hybridization, although there needs to be closer examination of this issue with the extensive comparative demographic data collected from throughout the species range (e.g., Forsman et al. 1996; Seaman et al. 1999; Blakesley et al. 2001). Further, it can take many years for these effects to become obvious (Price \& Bouvier 2002).

Fitness due to intraspecific hybridization may be reduced and local adaptations may be lost over time, however, these local adaptations may not be recognized if they are essential only during occasional extreme conditions (Allendorf et al. 2001). For example, while California spotted owls in northern Califonia and northern spotted owls in southern Oregon occupy the same or similar habitats, one striking difference between the subspecies is that some California spotted owls in the Sierras undertake an altitudinal migration in extreme winters (Laymon 1988). The effect of the potential loss of this adaptation in hybrid owls in Oregon is unknown but should be considered. Finally, in addition to intraspecific hybridization, interspecific hybridization with barred owls is occurring in both northern and California subspecies (Hamer et al. 1994; Dark et al. 1998; Kelly et al. 2003; Kelly \& Forsman 2004; Haig et al. 2004). These hybrids produce viable offspring, but rates of hybridization appear to be low (Kelly \& Forsman 2004), so it is not clear how extensively this will effect subsequent gene pools.

Our data suggest weak support for the traditional Mexican and California spotted owl relationship at the subspecies level. Barrowclough et al. (1999) reported three separate subspecies based on primary differentiation of northern spotted owls from a California and Mexican spotted owl sister group, although evidence for gene flow was found across the three subspecies. Haig et al. (2001) concluded that Mexican spotted owls were an evolutionary significant unit relative to California and northern spotted owls. However, there were only three Mexican spotted owl and two California spotted owl breeding areas examined. Neither previous study contained the 
extensive geographic sampling presented in the current study.

While there are no specific guidelines (e.g., rates of sequence divergence) for what level of differentiation constitutes an avian subspecies. One criteria suggested has been reciprocal monophyly which we do not have between California and Mexican spotted owls. Further, there are no morphological or other distinct differences between the groups. While lack of subspecies differences may be problematic from a current ESA listing perspective, Zink (2003) convincingly argues not to base units for listing on subspecific designation in the first place. Rather, identification of distinctive population structure is more relevant to conservation.

\section{Population genetic structure and status}

The genetic status of spotted owls is difficult to characterize as it varies tremendously among areas. Exact population estimates and overall population trends are not known for spotted owls although recent analysis of mark-recapture data suggest the spotted owl populations are declining in some areas and relatively stable in others ( $\mathrm{La}$ Haye 1992; Forsman et al. 1996; Seaman et al. 1999; Franklin et al. 2000, 2004; Blakesly et al. 2001). However, we estimate there are about 18,000 owls (approximately 12,000 northern spotted owls, E. Forsman, unpub. data; 4000 California spotted owls, G. Gould, California Fish and Game, pers. comm; and perhaps 1500 Mexican spotted owls, Gutiérrez et al. 1995) distributed over a vast portion of western North America. Comparison of these data and other demographic data (i.e., Forsman et al. 2002; Franklin et al. 2004) with mismatch distributions suggest that a large degree of population expansion has not taken place. Moreover, considering that female spotted owls disperse further than males (Forsman et al. 2002) and the maternal inheritance of mitochondrial DNA, our results represent a more optimistic view of population status than if paternally inherited markers were considered as well.

Among our characterization of northern spotted owls, estimates of gene flow and genetic diversity are affected by inclusion of birds carrying California spotted owl haplotypes in all but one region (Olympic). Comparative RAPD data suggest low levels of genetic diversity and significant differentiation among breeding areas and regions (Haig et al. 2001). This is corroborated by field data suggesting that most male spotted owls settle within four territory widths of their natal site whereas most females settle within seven territory widths of their natal site (Forsman et al. 2002). Finally, northern spotted owls occur in only $29 \%$ of their former range further suggesting reduced population viability (Gutiérrez 1994).

Among California spotted owls, there is a pronounced lack of genetic diversity, particularly in the southern California samples as evidenced in estimates of haplotype and nucleotide diversity. Lack of diversity in the southern California breeding areas may reflect a unique founding event by a few individuals and small population size. Recent population estimates do not exceed 300350 pairs throughout the southern California "archipelago" of habitat (Noon \& McKelvey 1992). Further, La Haye (1992) estimated that spotted owls in the San Bernadino Mountains declined significantly between 1987 and 1993 and no dispersal was observed between the San Bernadino and San Jacinto mountains (La Haye et al. 1994). Rapid habitat alteration and fragmentation in southern California may also contribute to this lack of diversity. Sierra breeding areas also indicated signs of declining abundance or a recent bottleneck. Recent demographic studies (1990-1999) corroborated these results for at least the Lassen National Forest, where data indicated a significant annual decline from 1990 to 2000 (Blakesley et al. 2001; Franklin et al. 2004). Thus, this may never have been a large population and it is distributed over a large geographic region with significant historic habitat gaps and more recent fragmentation in the Sierras and southern California.

An alternative hypothesis proposed by Barrowclough et al. (1999) suggests that there may be a recent advantageous mutant haplotype that has swept through these areas. This would result in elimination of some previous haplotype diversity. While possible, consideration should be made of the means and speed by which this mutant haplotype would be transmitted over such a sparse and widely distributed range in a subspecies with limited dispersal.

Mexican spotted owls have a far more fragmented distribution than the other two subspecies, 
with an estimated 1500 individuals found in the isolated mountains and canyonlands of the arid southwestern U.S. and Mexico. Genetic data reflected this dispersion with a $F_{\mathrm{ST}}$ that was 22 times larger than estimates for the other subspecies. Further, over one third of between-breeding area comparisons resulted in a significant differentiation. Breeding areas in Utah were often significantly different from breeding areas further south. Dispersal data support these results where, similar to northern spotted owls, most juveniles observed in Arizona did not disperse more than a few territories from their natal sites (Ganey et al. 1998). The median dispersal distance in northern Arizona was $16.6 \mathrm{~km}$ (Ganey et al. 1998) and $25.7 \mathrm{~km}$ in Utah (Willey \& van Riper 2000). Finally, owls in the Coconino Plateau and Tularosa Mountains have undergone significant annual declines further suggesting genetic and/or demographic issues of concern (Seaman et al. 1999).

\section{Conservation and population management in spotted owls}

This comprehensive assessment of spotted owl population genetic structure adds critical information to be considered in developing management actions to benefit the species. Despite mixing in a hybrid zone in southern Oregon, the clear genetic distinctions between California and northern spotted owls suggest that it is appropriate to continue recovery efforts for northern spotted owls based on traditional geographic subspecies. Similarly, we do not believe that lack of significant genetic differences between California and Mexican spotted owls is a reason for abandoning conservation efforts. Rather, lack of genetic diversity in the highly fragmented and declining southern California breeding areas and high population fragmentation among Mexican spotted owls suggests the need for close attention to the management of owls in both regions.

\section{Acknowledgements}

Success of this project was contingent on the cooperation of many spotted owl biologists from throughout the species' range. We thank the following individuals and their agencies or institutions for assistance in collecting samples:
R. Anthony, J. Blakesley, L. Diller, R. Forsan, R. Gerhardt, M. Hansen, G. King, P. Loschl, J. Reed, D. Rock, B. Sheehy, S. Sovern, G. Steger, J. Thrailkill, F. Wagner, and B. Woodbridge. Further, we thank M. Blouin and R. Waples for comments on the manuscript, R. Zink for advice on interpretation of mismatch distributions, and F. Allendorf, B. Noon, and R. Zink for preprints of papers. This project was funded by the USGS Forest and Rangeland Ecosystem Science Center.

\section{References}

Akaike H (1974) The new look at the statistical model identification. IEEE Trans. Autom. Contr., AC-19, 716-723.

Allendorf FW, Leary RF (1988) Conservation and distribution of genetic variation in a polytypic species, the Cutthroat Trout. Conserv. Biol., 2, 170-184.

Allendorf FW, Leary RF, Spruell P, Wenburg JK (2001) The problem with hybrids: setting conservation guidelines. TREE, 16, 613-622.

American Ornithologists' Union (1957) Checklist of North American Birds. Fifth edition, American Ornithologists Union, Washington, DC.

Aris-Brosou S, Excoffier L (1996) The impact of population expansion and mutation rate heterogeneity on DNA sequence polymorphism. Mol. Biol. Evol., 13, 494-504.

Avise JC (1994) Molecular Markers, Natural History and Evolution. Chapman \& Hall, New York.

Avise JC (2000) Phylogeography. Harvard University Press, Cambridge MA.

Avise JC, Ankney CD, Nelson WS (1990) Mitochondrial gene trees and the evolutionary relationship of Mallard and Black Ducks. Evolution, 44, 1109-1119.

Avise JC, Nelson WS (1989) Molecular genetic relationships of the Dusky Seaside Sparrow. Science, 243, 646-648.

Avise JC, Walker D (1998) Pleistocene phylogeographic effects on avian populations and the speciation process. Proc. $R$. Soc. Lond. B, 265, 457-463.

Baker AJ, Marshall HD (1997) Mitochondrial control region sequences as tools for understanding evolution. In: Avian Molecular Evolution (ed. DP Mindell), pp. 160-189. Academic Press, NY.

Barrowclough GF, Gutiérrez RJ, Groth JG (1999) Phylogeography of spotted owl (Strix occidentalis) populations based on mitochondrial DNA sequences: gene flow, genetic structure, and a novel biogeographic pattern. Evolution, 53, 919-931.

Beerli P, Felsenstein J (1999) Maximum likelihood estimation of migration rates and effective population numbers in two populations using a coalescent approach. Genetics, 152, 763-773.

Beerli P, Felsenstein J (2001) Maximum likelihood estimation of a migration matrix and effective population sizes in $n$ subpopulations by using a coalescent approach. PNAS, 98, 4563-4568.

Bensch S, Andersson T, Akesson S (1999) Morphological and molecular variation across a migratory divide in Willow Warblers, Phylloscopus trochilus. Evolution, 53, 1925-1935. 
Bernatchez L (1995) A role for molecular systematics in defining evolutionary significant units in fishes. Am. Fish. Soc. Symp., 17, 114-132.

Blakesley JA, Noon BR, Shaw DWH (2001) Demography of the California spotted owl in northeastern California. Condor, 103, 667-677.

Brown WM, George M, Jr., Wilson AC (1979) Rapid evolution of animal mitochondrial DNA. Proc. Nat. Acad. Sci USA, 76, 1967-1971.

Clement M, Posada D, Crandall KA (2000) TSC: a computer program to estimate gene genealogies. Molec. Ecol., 9, 16571659.

Crandall KA, Bininda-Edmonds ORP, Mace GM, Wayne RK (2000) Considering evolutionary processes in conservation biology. TREE, 15, 290-295.

Dark SJ, Gutiérrez RJ, Gould GI (1998) The barred owl (Strix varia) invasion in California. Auk, 115, 50-56.

Felsenstein J (1985) Confidence limits on phylogenies: an approach using the bootstrap. Evolution, 39, 783-791.

Firestone KB, Elphinstone MS, Sherwin WB, Houlden BA (1999) Phylogeographical population structure of Tiger Quolls Dasyurus maculatus (Dasyuridae: Marsupialia), an endangered carnivorous marsupial. Mol. Ecol., 8, 1613-1625.

Fleischer RC, Rothstein SI, Miller LS (1991) Mitochondrial DNA variation indicates gene flow across a zone of known secondary contact between two subspecies of the Brownheaded Cowbird. Condor, 93, 185-189.

Forsman ED, DeStefano S, Raphael MG, Gutiérrez RJ (eds) (1996) Demography of the northern spotted owl. Stud. Avian Biol., 17.

Forsman ED, Meslow EC, Wight HM (1984) Distribution and biology of the Spotted Owl in Oregon. Wildl. Mono., 87.

Forsman ED, Reid J, Biswell B, Loschl P, Sovern S, Taylor M, Anthony R, Ellingson A, Swindle K, Thrailkill J, Wagner F. (2002). Natal and postnatal dispersal of northern spotted owls. Wildl. Mono. 149.

Franklin AB, Anderson DR, Gutiérrez RJ, Burnham KP (2000) Climate, habitat quality and fitness in northern spotted owl populations in western California. Ecol. Mono. 70: 539-590.

Franklin AB, Gutiérrez RJ, Nichols, JD, Seamans ME, White GC, Zimmerman GS, Hines JE, Munton TE, LaHaye WS, Blakesley JA, Steger GN, Noon BR, Shaw DWH, Keane JJ, McDonald TL, Britting S. (2004) Population dynamics of the California spotted owl (Strix occidentalis occidentalis): a meta-analysis.

Fu YX, Li WH (1993) Statistical tests of neutrality of mutations. Genetics, 133, 693-709.

Ganey JL, Block WM, Dwyer JK, Strohmeyer BE, Jenness JS (1998) Dispersal movements and survival rates of juvenile Mexican spotted owls in northern Arizona. Wilson Bull., 110, 206-217.

Glenn TC, Thompson JE, Ballard BM, Roberson JA, French JO (2002) Mitochondrial DNA variation among wintering midcontinent Gulf Coast Sandhill Cranes. J. Wildl. Mgmt., 66, 339-348.

Goodstrey A, Carss DN, Noble R, Piertney SB (1998) Population introgression and differentiation in the Great Cormorant Phalacrocorax carbo in Europe. Mol. Ecol., 7, 329-338.

Gutiérrez RJ (1994) Changes in the distribution and abundance of spotted owls during the past century. Stud. Avian Biol., 15, 293-300.

Gutiérrez RJ, Franklin AB, La Haye WS (1995) spotted owls (Strix occidentalis). In: The Birds of North America (eds.
Poole A, Gill F), Vol. 179. The Academy of Natural Sciences, Philadelphia, and the American Ornithologists' Union, Washington, DC.

Haig SM, Allendorf FW (2004) Hybrid policies under the U.S. Endangered Species Act. In: The Endangered Species Act at Thirty: Lessons and Prospects (eds Davis F, Goble DD, Heal G, Scott JM). Island Press, New York.

Haig SM, Rhymer JM, Heckel DG (1994) Population differentiation in randomly amplified polymorphic DNA of Redcockaded Woodpeckers. Mol. Ecol., 3, 581-595.

Haig SM, Wagner RS, Forsman ED, Mullins TD (2001) Geographic variation and genetic structure in spotted owls. Conserv. Genet., 2, 25-40.

Haig SM, Wennerberg L, Mullins TD, Forsman ED, Trail P (2004) Genetic identification of spotted owls, barred owls, and their hybrids: evolutionary and legal implications. Conserv Biol., 18, 1347-1357.

Haldane JBS (1922) Sex ratio and unisexual sterility of hybrid animals. J. Genet., 12, 101-109.

Hamer TE, Forsman ED, Fuchs AD, Walters ML (1994) Hybridization between Barred and spotted owls. Auk, 111, 487-492.

Huelsenbeck JP, Crandall KA (1997) Phylogeny estimation and hypothesis testing using maximum likelihood. Ann. Rev. Ecol. Syst., 28, 437-466.

Irwin DE (2002) Phylogeographic breaks without geographic barriers to gene flow. Evol., 56, 2383-2394.

Kelly EG (2001) The range expansion of the northern barred owl: an evaluation of the impact on spotted owls. M.S. Thesis, Oregon State University, Corvallis OR, 78 pp.

Kelly EG, Forsman ED, Anthony RG (2003) Are barred owls displacing spotted owls? Condor, 105, 45-53.

Kelly EG, Forsman ED (2004) Recent records of hybridization between barred owls (Strix varia) and northern spotted owls (S. occidentalis caurina). Auk, 121, 806-810.

Kimura M (1983) The Neutral Theory of Molecular Evolution. Cambridge University Press, Cambridge, UK.

Klicka J, Zink RM (1997) The importance of recent ice ages in speciation: a failed paradigm. Science, 277, 1666-1669.

Kuhner MK, Yamato J, Felsenstein J (1995) Estimating effective population size and neutral mutation rate from sequence data using Metropolis-Hastings sampling. Genetics, 140, 1421-1430.

La Haye WS, Gutiérrez RJ, Akcakaya HR (1994) Spotted owl metapopulation dynamics in southern California. J. Anim. Ecol., 63, 775-785.

La Haye WS, Gutiérrez RJ, Call DR (1992) Demography of an insular population of spotted owl (Strix occidentalis occidentalis). In: Wildlife 2001: Populations (eds. McCullough D, Barrett RH). Elsevier Press, NY.

Laymon SD (1988) The ecology of the spotted owl in the central Sierra Nevada, California. Ph.D. dissertation, University of California, Berkeley.

Lovette IJ, Bermingham E, Ricklefs RE (1999) Mitochondrial DNA phylogeography and the conservation of endangered Lesser Antillean Icterus Orioles. Conserv. Biol., 13, 10881096

Mantel NA (1967) The detection of disease clustering and a generalized regression approach. Cancer Res., 27, 209-220.

Miller GS, Small RJ, Meslow EC (1997) Habitat selection by spotted owls during natal dispersal in western Oregon. $J$. Wildl. Manage., 61, 140-150.

Nei M (1987) Molecular Evolutionary Genetics. Columbia University Press, New York. 
Nelson WS, Dean T, Avise JC (2000) Matrilineal history of the endangered Cape Sable Seaside Sparrow inferred from mitochondrial DNA polymorphism. Mol. Ecol., 9, 809-813.

Noon BR, KS McKelvey (1992) Stability properties of the spotted owl metapopulation in southern California. In: The California spotted owl: A Technical Assessment of its Current Status (eds. Verner J, McKelvey KS, Noon BR, Gutiérrez RJ, Gould GI, Jr., Beck TW), pp. 187-206. General Technical Report PSW-GTR-133. USDA Forest Service, Albany, CA.

Oberholser HC (1915) Critical notes on the subspecies of spotted owl (Strix occidentalis) (Xantus). Proc. U.S. Nat. Mus. 49, 251-257.

Oring LW, Able KP, Anderson DW, Baptista LF, Barlow JC, Gaunt AS, Gill FB, Wingfield JC (1988). Guidelines for the Use of Wild Birds in Research. Auk, 105,(supplement), 1A-44A.

Parker KM, Sheffer RJ, Hedrick PW (1999) Molecular variation and evolutionary significant units in the endangered Gila Topminnow. Conserv. Biol., 13, 108-116.

Posada D, Crandall KA (1998) Modeltest: testing the model of DNA substitution. Bioinformatics, 14, 817-818.

Posada D, Crandall KA, Templeton AR (2000) GeoDis: a program for the cladistic nested analysis of the geographical distribution of genetic haplotypes. Mol. Evol., 9, 487-488.

Price TD, Bouvier MM (2002) The evolution of $F_{1}$ postzygotic incompatibilities in birds. Evol., 56, 2083-2089.

Rhymer JM, Fain MG, Austin JE, Johnson DH, Krajewski C (2001) Mitochondrial phylogeography, subspecific taxonomy, and conservation genetics of sandhill cranes (Grus canadensis; Aves: Gruidae). Conserv. Genet., 2, 203-218.

Rhymer JM, Simberloff D (1996) Extinction by hybridization and introgression. Ann. Rev. Ecol. Syst., 27, 83-109.

Rice WR (1989) Analyzing tables of statistical tests. Evolution, 43, 223-225.

Rogers AR (1995) Genetic evidence for a Pleistocene population explosion. Evolution, 49, 608-615.

Rogers AR, Harpending HC (1992) Population growth makes waves in the distribution of pairwise genetic differences. Mol. Biol. Evol., 9, 552-569.

Rohwer S, Bermingham E, Wood C (2001) Plumage and mitochondrial DNA haplotype variation across a moving hybrid zone. Evolution, 55, 405-422.

Roman J, Santhuff SD, Moler PE, Bowen BW (1999) Population structure and cryptic evolutionary units in the Alligator Snapping Turtle. Conserv. Biol., 13, 135-142.

Rozas J, Rozas R (1999) DNASP version 3: an integrated program for molecular population genetics and molecular evolutionary analysis. Bioinformatics, 15, 174-175.

Sattler GD, Braun MJ (2000) Morphometric variation as an indicator of genetic interactions between Black-capped and Carolina Chickadees at a contact zone in the Appalachian Mountains. Auk, 117, 427-444.

Schneider S, Excoffier L (1999) Estimation of demographic parameters from the distribution of pairwise differences when the mutation rates vary among sites: application to human mitochondrial DNA. Genetics, 152, 1079-1089.

Schneider S, Roessli D, Excoffier L (2000) Arlequin ver 2.000: a software for population genetic data analysis. Genetics and Biometry Laboratory, University of Geneva, Switzerland.

Seaman ME, Gutiérrez RJ, May CA, Perry MZ (1999) Demography of two Mexican spotted owl populations. Conserv. Biol., 13, 744-754.
Seutin G, Brawn J, Ricklefs RE, Bermingham E (1993) Genetic divergence among populations of a tropical passerine, the Streaked Saltator (Saltator albicollis). Auk, 110, 117-126.

Slatkin M (1991) Inbreeding coefficients and coalescence times. Genet Res., 58, 167-175.

Slatkin M (1995) A measure of population subdivision based on microsatellite frequencies. Genetics, 139, 457-462.

Soltis DE, Gitzendanner MA, Strenge DD, Soltis PS (1997) Chloroplast DNA intraspecific phylogeography of plants from the Pacific Northwest of North America. Pl. Syst. Evol., 206, 353-373.

Sorenson MD, Ast JC, Dimcheff DE, Mindell YT (1999) Primers for a PCR-based approach to mitochondrial genome sequencing in birds and other vertebrates. Mol. Phyl. Evol., 12, 105-114.

Swofford DL (2002) Phylogenetic Analysis Using Parsimony (PAUP*), version 4.0b9. Smithsonian Institution, Washington, DC.

Tajima F (1983) Evolutionary relationship of DNA sequence in finite populations. Genetics, 105, 437-460.

Tajima F (1989) Statistical method for testing the neutral mutation hypothesis by DNA polymorphism. Genetics, 123, 585-595.

Tajima F (1993) Measurement of DNA polymorphism. In: Mechanisms of Molecular Evolution (eds. Takahata N, Clark AG), pp. 37-59. Japan Scientific Societies Press, Sinauer Associates, Sunderland MA.

Tajima F (1996) The amount of DNA polymorphism maintained in a finite population where the neutral mutation rates varies among sites. Genetics, 143, 1457-1465.

Takezaki N, Rzhetsky A, Masatoshi N (1995) Phylogenetic test of the molecular clock and linearized trees. Molec. Evol., 12(5), 823-833.

Tamura K, Nei M (1993) Estimation of the number of nucleotide substitutions in the control region of mitochondrial DNA in humans and chimpanzees. Molec. Biol. Evol., 10, 512-526.

Tegelstrom H, Gelter HP (1990) Haldane's rule and sex biassed gene flow between two hybridizing flycatcher species (Ficedula albicollis and F. hypoleuca, Aves: Muscicapidae). Evolution, 44, 2012-2021.

Templeton AR (1998) Nested clade analysis of phylogeographic data: testing hypothesis about gene flow and population history. Mol. Ecol. 7, 3381-3397.

Templeton AR, Boerwinkle E, Sing CF (1987) A cladistic analysis of phenotypic associations with haplotypes inferred from restriction endonuclease mapping. I. Basic theory and an analysis of alcohol dehydrogenase activity in Drosophila. Genetics, 117, 343-351.

Templeton AR, Routman E, Phillips CA (1995) Separating population structure from population history: A cladistic analysis of the geographical distribution of mitochondrial DNA haplotypes in the Tiger Salamander, Ambystoma tigrinum. Genetics, 140, 767-782.

Templeton AR, Sing CF (1993) A cladistic analysis of phenotypic associations with haplotypes inferred from endonuclease mapping. IV. Nested analysis with cladogram uncertainty and recombination. Genetics, 134, 659-669.

Thomas JW, Forsman ED, Lint JB, Meslow EC, Noon BR, Verner J (1990) A conservation strategy for the northern spotted owl. Interagency Scientific Committee to Address the Conservation of the northern spotted owl, 427 pp. US Fish and Wildlife Service Portland, OR. 
US Fish and Wildlife Service (1995) Recovery plan for the Mexican spotted owl (Strix occidentalis lucida). US Fish and Wildlife Service, Albuquerque, NM.

US Forest Service and US Bureau of Land Management (1994) Final Supplemental Environmental Impact Statement on Management of Habitat for Inter-successional and Old Growth Forest-related Species within the Range of the northern spotted owl. 2 vols. + maps. Washington DC.

Verner J, Gutiérrez RJ, Gould GI, Jr. (1992) The California spotted owl: general biology and ecological relations. In: The California spotted owl: A Technical Assessment of Its Current Status (eds. Verner J, McKelvey KS, Noon BR, Gutiérrez RJ, Gould GI, Jr., Beck TW), pp. 187-206. General Technical Report PSW-GTR-133. USDA Forest Service, Albany, CA.

Willey DW, Van Riper III C (2000) First-year movements by juvenile Mexican Spotted Owls in the Canyonlands of Utah. J. Raptor Res., 34, 1-7.

Wolf DE, Takebayashi N, Rieseberg LH (2001) Predicting the risk of extinction through hybridization. Conserv. Biol., 15, 1039-1053.
Wright S (1931) Evolution in Mendelian populations. Genetics, 16, 97-159.

Young DL, Allard MW (1997) Conservation genetics of the Plain Pigeon Columba inornata in Puerto Rico and the Dominican Republic. Mol. Ecol., 6, 877-879.

Zink RM (1994) The geography of mitochondrial DNA variation, population structure, hybridization, and species limits in the Fox Sparrow (Passerella iliaca). Evolution, 48, 96-111.

Zink RM (2003) The role of subspecies is obscuring avian biological diversity and misleading conservation policy. Proc. R. Soc. Lond. B, 03pb0798.1-03pb0798.4.

Zink RM, Barrowclough GF, Atwood JL, Blackwell-Rago RC (2000) Genetics, taxonomy, and conservation of the threatened California Gnatcatcher. Conserv. Biol., 14, 1394-1405.

Zink RM, Kesson AE, Line TV, Blackwell-Rago RC (2001) Comparative phylogeography of some aridland bird species. Condor, 103, 1-10.

Zink RM, Rootes WL, Dittmann DL (1991) Mitochondrial DNA variation, population structure, and evolution of the Common Grackle (Quiscalus quiscalus). Condor, 93, 318329. 